University of New Hampshire

University of New Hampshire Scholars' Repository

Faculty Publications

$1-1-2019$

\title{
Vernal Pool Conservation: Enhancing Existing Regulation Through the Creation of the Maine Vernal Pool Special Area Management Plan
}

\author{
Vanessa R. Levesque \\ University of New Hampshire, Durham, Vanessa.Levesque@unh.edu \\ Aram J. K. Calhoun \\ University of Maine, Orono \\ Elizabeth Hertz \\ Blue Sky Planning Solutions
}

Follow this and additional works at: https://scholars.unh.edu/faculty_pubs

Comments

This is an article published by University of California Press in Case Studies in the Environment in 2019, available

online: https://dx.doi.org/10.1525/cse.2018.001636

\section{Recommended Citation}

Levesque, V.R., Calhoun, A.J.K., Hertz, E. 2019. Vernal pool conservation: Innovative approaches to using and enhancing existing policy tools. Case Studies in the Environment.

This Article is brought to you for free and open access by University of New Hampshire Scholars' Repository. It has been accepted for inclusion in Faculty Publications by an authorized administrator of University of New Hampshire Scholars' Repository. For more information, please contact Scholarly.Communication@unh.edu. 


\title{
Vernal Pool Conservation: Enhancing Existing Regulation Through the Creation of the Maine Vernal Pool Special Area Management Plan
}

\section{VANESSA R. LEVESQUE ${ }^{1}$, ARAM J. K. CALHOUN ${ }^{2}$ AND ELIZABETH HERTZ ${ }^{3}$}

'University of New Hampshire, Durham, NH USA, ${ }^{2}$ University of Maine, Orono, ME USA,

${ }^{3}$ Blue Sky Planning Solutions, Bowdoin, ME USA

Email: vanessa.levesque@unh.edu

\begin{abstract}
Conservation of natural resources is challenging given the competing economic and ecological goals humans have for landscapes. Vernal pools in the northeastern US are seasonal, small wetlands that provide critical breeding habitat for amphibians and invertebrates adapted to temporary waters, and are exceptionally hard to conserve as their function is dependent on connections to other wetlands and upland forests. A team of researchers in Maine joined forces with a diverse array of governmental and private stakeholders to develop an alternative to existing topdown vernal pool regulation. Through creative adoption and revision of various resource management tools, they produced a vernal pool conservation mechanism, the Maine Vernal Pool Special Management Area Plan that meets the needs of diverse stakeholders from developers to ecologists. This voluntary mitigation tool uses fees from impacts to vernal pools in locally identified growth areas to fund conservation of "poolscapes" (pools plus appropriate adjacent habitat) in areas locally designated for rural use. In this case study, we identify six key features of this mechanism that illustrate the use of existing tools to balance growth and pool conservation. This case study will provide readers with key concepts that can be applied to any conservation problem: namely, how to work with diverse interests toward a common goal, how to evaluate and use existing policy tools in new ways, and how to approach solutions to sticky problems through a willingness to accept uncertainty and risk.
\end{abstract}

\section{INTRODUCTION}

Vernal pools in the northeastern United States are ephemeral wetlands that provide breeding habitat to amphibian and invertebrate species adapted to life in these fishless, temporary waters, resting or foraging habitat to a suite of other species, and ecosystem system functions related to hydrology, water quality, and biogeochemical processes $[\mathrm{I}-3]$. Small, natural features, such as vernal pools [4] are challenging to conserve through traditional regulatory mechanisms, are hard to inventory because they are small and only temporarily inundated, and often are seen as having little ecological value given their small size [s]. Yet there is a vast body of literature describing the role of vernal pools as critical breeding habitat for pool-breeding amphibians in northeastern North America and as critical components of our biological, hydrological, and biogeochemical landscapes $[1,6-8]$.
Unfortunately, the regulatory protections for vernal pools do not reflect the scale of functions scientifically documented by these small natural features throughout the forests in the northeastern US.

Vernal pool ecosystems are particularly hard to conserve as they are inextricably intertwined with adjacent forested habitat for the pool breeding amphibians [e.g., wood frogs (Lithobates sylvaticus) and ambystomatid salamanders (Ambystoma spp.)] that use the pools for at most 3 weeks as breeding sites. These pool-breeding amphibians need intact forested habitat as far as $\mathrm{I}, 000 \mathrm{ft}(\sim 290 \mathrm{~m})$ from the breeding pool to support a significant portion of the adult population and much longer distances for juvenile dispersal [9, го]. The negative effects of habitat fragmentation, and more specifically, urbanization, on vernal pool breeding amphibians are welldocumented [II-I4]. In this case study, we describe the Maine Vernal Pool Special Area Management Plan (SAMP)

Case Studies in the Environment, 2019 , pps. I-8. electronic ISSN 2473-95 10. () 2019 by the Regents of the University of California. All rights reserved. Please direct all requests for permission to photocopy or reproduce article content through the University of California Press's Reprints and Permissions web page, www.ucpress.edu/journals.php?p=reprints. DOI: https://doi.org/10.1 525/cse.2018.001636 
that emerged from a collaborative process to address dissatisfaction with existing vernal pool regulation.

\section{CASE EXAMINATION}

Existing Vernal Pool Regulations in Maine

Vernal pools are regulated at the federal level under Section 404 of the Clean Water Act [as administered by the US Army Corps of Engineers (ACOE)]. Many are not within the jurisdiction of the ACOE owing to lack of adjacency to waters of the US (defined as "navigable" waters). Determination of regulatory relevance is generally made on a case-by-case basis with limited flexibility to account for landscape setting, distance from other pools or wetlands, or quality of the adjacent terrestrial habitat for pool-breeding amphibians [8]. Under federal regulation in the United States, vernal pools are considered "geographically isolated" wetlands. This designation puts many constraints on their regulation at the federal level, a reality that trickles down to state regulations [I, 7]. Additionally, in Maine, the Maine Natural Resources Protection Act (38 MRSA 480) lays out the statutory authority for the regulation of a small subset of vernal pools that are identified and mapped as Significant Wildlife Habitat by the Maine Department of Inland Fisheries and Wildlife (MDIFW) using narrowly defined biological criteria $[8, \mathrm{I} 5]$.

\section{Effort to Create a New Vernal Pool Conservation Mechanism}

Creed et al. [8] urge more local and landscape-scale approaches to wetland conservation in place of the current top-down mechanisms that regulate a small subset of the resource as "isolated" units. There has been an effort to address this goal in Maine, USA, through the work of a diverse array of stakeholders to develop a locally driven vernal pool conservation mechanism that recognizes the landscape functions of vernal pools. Regulators at local, state, and federal levels of government, the development community, economists, biologists, planners, land trusts, and municipal officials collaborated to create the Maine Vernal Pool SAMP. These stakeholders came together because of their mutual discontent with the existing federal and state vernal pool regulations (Table I). They identified a common goal of tailoring the existing top-down system to one driven by local control with better conservation outcomes for vernal pool ecosystems, more predictability for the regulated community, and support of local goals for growth and resource protection. This experiment in innovation among stakeholders with very diverse missions, and even traditionally adversarial positions regarding wetland conservation, is the topic of our case study.

\section{Background on the Vernal Pool SAMP}

Authorized through the Coastal Zone Management Act of I 980 ( I 6 USC I 453 [ I 7 ]), SAMPs are comprehensive plans balancing natural resource protection and economic growth. They contain a detailed and comprehensive statement of policies, standards, and implementation mechanisms. Common tools used in a SAMP might include federal and state wetland regulations, municipal ordinances, and marketbased fee structures. As such, they may provide the additional flexibility needed for the regulation and protection of resources that are challenging to conserve.

The Maine Vernal Pool SAMP is a conservation-based mitigation option that acknowledges the unique ecological functions of vernal pools and recognizes that pools embedded in development are not sustainable. The SAMP permits impacts to pools in a specific, preidentified portion of a municipality's comprehensive planidentified growth area called the Designated Development Area (DDA) in exchange for payment of a fee by the permit applicant. The fee is based on a current appraisal of the property that includes a value for the property in its "as is" condition with the vernal pool(s) and a value for the property as if the vernal pool(s) did not exist. The applicant pays a predetermined percentage of the difference between the two values ( $40 \%$ as of this writing) to the municipality. The municipality issues the permit and transfers the fee to a partnering non-governmental organization, most likely a land trust. The land trust then undertakes conservation actions to conserve high-quality vernal pool conservation targets in the rural area of the municipality (Figure I). Finally, the SAMP is voluntary; a municipality must request authority from the State to implement it, and a landowner impacted by a vernal pool on their property can choose to abide by existing state and federal regulations or to proceed under the SAMP.

The SAMP was the outcome of a multi-year collaborative process based on the participation of a range of stakeholders with different experiences, knowledge, and needs. During this collaboration, trust was developed and power was shared between traditional adversaries, and participants learned from each other and co-created new knowledge $[16,19-20]$. This process encouraged respectful discussion, sharing of ideas and generation of solutions, and, in doing so, created the atmosphere in 
TABLE 1. Major stakeholder groups and associated concerns with existing regulatory structure

\begin{tabular}{l} 
Stakeholder group \\
\hline Federal (ACOE, USFWS, and USEPA) \\
and state agencies (MDEP, MDIFW, \\
DACF, and MDECD)
\end{tabular}

Municipal officials (e.g., Planner and Planning Boards, Economic Development Director, Select Boards, and Councilors)

Landowners with vernal pools and applicants for development permits

Land trusts

University researchers and consultants (e.g., ecologist, planner, and economist)

\section{Major concerns with existing regulations}

- Federal and state regulations for vernal pools have different standards and are perceived to lack clarity and predictability. As a result, the regulators frequently spend a lot of time working with confused and upset landowners

- Permit determinations have to be made on a case-by-case basis, which is time consuming and costly

- Vernal pools are hard to identify remotely and are costly to survey

- Recognition that laws fall short of protecting long-term functionality of vernal pool ecosystems

- Not knowing where regulated vernal pools are located makes it difficult to do town-wide planning

- Possible loss of tax revenue when developments relocate elsewhere because of vernal pools

- Perception of vernal pools causing yet another regulatory hoop in development projects

- Having to navigate both state and federal regulatory systems that lack predictability, consistency, and clarity

- Inability to develop part or all of a property due to presence of vernal pools

- Not knowing if a vernal pool exists on a property or if it will be regulated

- Development delays driven by spring pool surveys required to determine if a pool meets regulatory criteria

- Costly alternatives analyses

- Initially thought vernal pool regulations were good because they at least protected vernal pools to some degree and were fearful of attempts to change existing regulations.

- Less standing as second-tier stakeholders not directly impacted

- Concern for long-term sustainability of vernal pool ecosystems and economic vitality of Maine towns under current regulatory framework

ACOE, US Army Corps of Engineers; USFWS, US Fish and Wildlife Service; USEPA, US Environmental Protection Agency; MDEP, Maine Department of Environmental Protection; MDIFW, Maine Department of Inland Fisheries and Wildlife; MDACF, Maine Department of Agriculture, Conservation and Forestry; MDECD, Maine Department of Economic and Community Development.

which participants felt empowered to propose innovative options. Thus, this mechanism is not only noteworthy in how it might protect the resource but also in how it helped reduce conflict between stakeholders who hold different values.

\section{Key Features of the SAMP Approach}

We identified six key features of this mechanism that illustrate the use of specific tools and approaches that were coupled with a collaborative approach to balancing local growth and long-term vernal pool conservation (Table 2 ). For each feature, we describe how it works and explain the way in which it is useful in this case.
NOVEL APPLICATION IN A NEW CONSERVATION ARENA The SAMP is being used as a vehicle for a new conservation mechanism for a resource that is dispersed across the landscape rather than as a resource management plan. SAMPs are most frequently used for regional planning by Coastal Zone Management programs, although they can be used at a smaller scale and for a smaller scope [ 17 ]. The ACOE Regulatory Guidance Letter o5-09 [ I 8] provides guidance for the use of SAMPs in non-coastal areas. Only a few have previously been approved by the ACOE, including one for wetland preservation in Superior, Wisconsin, and one for bank stabilization and flood confinement on the Upper Yellowstone River. 


\section{KEY STEPS IN IMPLEMENTING THE MAINE VERNAL POOL SAMP}

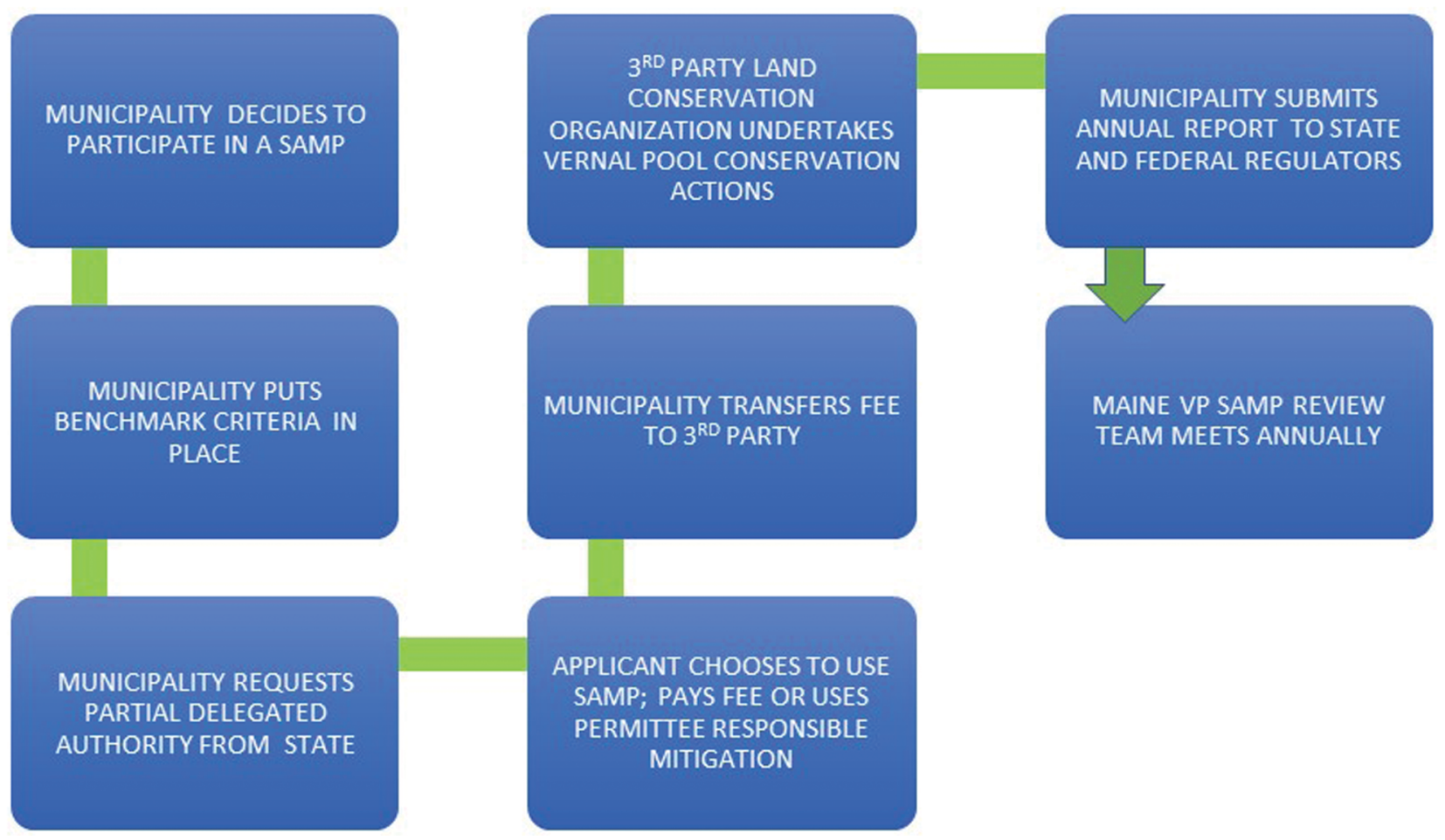

FIGURE 1. Key steps in implementing the Maine Vernal Pool SAMP. In order for a municipality to offer the SAMP as a mitigation option for impacts to vernal pools, it must meet certain criteria and request partial delegated authority from the State, as well as partner with a land conservation organization that will undertake the required conservation actions. The SAMP will be reviewed annually to identify any needed modifications.

LANDSCAPE-SCALE APPROACH The SAMP applies a biologically defined landscape-scale approach; that is, an approach to vernal pool conservation that stresses resource connectivity with adjacent forests and wetlands. The landscape approach recognizes that discrete vernal pools in a sea of development cannot function to their full potential.

The biologically defined landscape approach is applied to the regulatory framework in two tangible ways: ( $\mathrm{I}$ ) the avoidance and minimization analysis required for a permit to impact vernal pools is completed across the entire DDA rather than on a pool-by-pool basis; and (2) the location and amount of mitigation required for impacts to vernal pool impacts in the DDA reflects current research into the landscape-scale needs of pool-breeding amphibians. Two pools and adjacent habitat sufficient to sustain pool breeding amphibian species are protected in perpetuity for each pool impacted in the DDA (Figure 2).

DELEGATION OF AUTHORITY State and federal regulators worked together to develop a mechanism that would meet their regulatory requirements, while allowing municipalities to implement the mechanism through their local permitting processes. At the federal level, the ACOE regulates wetlands through the Clean Water Act. Maine has a general permit with the ACOE allowing the Maine Department of Environmental Protection (MDEP) to issue permits for certain types of wetland projects. The State, through the Maine Natural Resources Protection Act (Title 38 MRSA Section 450-F), may delegate its permitting authority to the municipal level. The SAMP uses 
TABLE 2. Key innovative features of vernal pool SAMP

\begin{tabular}{|c|c|}
\hline Key feature & Innovative aspect \\
\hline $\begin{array}{l}\text { 1. Using a SAMP as the vehicle for } \\
\text { the new conservation mechanism }\end{array}$ & $\begin{array}{l}\text { SAMPs are typically used by NOAA Coastal Zone Management Programs, and the few } \\
\text { examples of use by ACOE are for an entire watershed or river system. In this case, a } \\
\text { SAMP was applied to discrete, small freshwater wetlands dispersed across the landscape }\end{array}$ \\
\hline $\begin{array}{l}\text { 2. Landscape-scale approach to } \\
\text { vernal pool conservation }\end{array}$ & $\begin{array}{l}\text { Landscape analysis is often conducted for watershed plans, but is unlikely to be used in a } \\
\text { regulatory framework, when a resource is protected as an isolated unit. The Maine Vernal } \\
\text { Pool SAMP mechanism requires a landscape approach in two tangible ways: (1) The } \\
\text { location and amount of mitigation required for impacts to vernal pools considers } \\
\text { landscape-scale conservation elements for vernal pool resources. (2) The avoidance and } \\
\text { minimization analysis required for a vernal pool permit has been done for the entire } \\
\text { DDA based on landscape functions of vernal pools }\end{array}$ \\
\hline $\begin{array}{l}\text { 3. Permitting authority (state and } \\
\text { federal) transferred to local level }\end{array}$ & $\begin{array}{l}\text { Streamlining federal and state permitting usually entails developing a process by which } \\
\text { state and federal regulators work more closely together to issue permits } \\
\text { The SAMP takes streamlining in a different direction: state and federal regulators worked } \\
\text { together to develop a mechanism that would meet their regulatory requirements, and } \\
\text { then allows municipalities to set-up and implement the mechanism through their local } \\
\text { planning and permitting processes }\end{array}$ \\
\hline $\begin{array}{l}\text { 4. Mitigation fees tied to local } \\
\text { economic conditions using an } \\
\text { appraisal-based analysis of the } \\
\text { impacted property }\end{array}$ & $\begin{array}{l}\text { In this case, the fee calculation is based on an appraisal of the specific impacted property. } \\
\text { The fee calculation is based on the difference between the appraised value of the property } \\
\text { in its "as is" condition and the appraised value of the property as if the vernal pools were } \\
\text { not there. The fee is, therefore, directly tied to site-specific and time-specific economic } \\
\text { conditions unlike other more general mitigation fees }\end{array}$ \\
\hline $\begin{array}{l}\text { 5. Role of land trust as a formal } \\
\text { partner in supporting municipal } \\
\text { goals for both growth and resource } \\
\text { protection }\end{array}$ & $\begin{array}{l}\text { Land trusts are already beginning to work more closely with their communities to } \\
\text { identify conservation goals. This tool takes advantage of that movement and applies it to } \\
\text { conservation for mitigation of impacted regulated resources. The innovation is the formal } \\
\text { inclusion of the land trust as a partner with the community in implementing the Maine } \\
\text { Vernal Pool SAMP }\end{array}$ \\
\hline 6. Voluntary tool at multiple levels & $\begin{array}{l}\text { The SAMP provides a voluntary mechanism and expands the options available for } \\
\text { working with vernal pool impacts in growth areas without requiring new regulations }\end{array}$ \\
\hline
\end{tabular}

this hierarchical regulatory structure to move permitting authority from the federal to local level.

SITE-SPECIFIC MITIGATION fEe Mitigation fees are tied to local economic conditions through appraisal of the impacted property. The appraisal method relies on recent comparable sales, thus linking the mitigation fee directly to current, sitespecific economic conditions. The fee is a percentage of the difference in value of the parcel in its as-is condition with the vernal pool(s) and a value for the parcel as-if the vernal pool(s) did not exist. In 2018 , it is $40 \%$. While the use of a mitigation fee to compensate for impacts and fund conservation was not a new concept, Maine's statewide natural resource mitigation program, the Maine Natural Resource Conservation Program, uses county rates, calculated every 5-7 years, to determine the mitigation fee.

FORMAL LAND TRUST ROLE Land trusts, which are nonprofit organizations that conserve lands, are a formal partner in implementing the conservation conditions of the SAMP. In the SAMP, a local land trust is responsible for using the mitigation funds collected by the municipality for impacts to vernal pools to permanently conserve high quality vernal pools and surrounding landscapes. Although it is not unusual for land trusts to partner with municipalities in an ad-hoc way or in general conservation planning, formal partnering through a regulatory mechanism that supports municipal goals for both growth and resource protection is unusual. In doing so, land trusts are practicing community-based conservation, the land trust movement to work with communities to identify and protect places important to the community instead of "last best places."

VOLUNTARY The SAMP is a voluntary tool at all levels; the current regulations are default if the SAMP is not chosen. Municipalities must apply for delegated authority and set up the structure to implement the SAMP in their 
Vernal pool impacted in the DDA

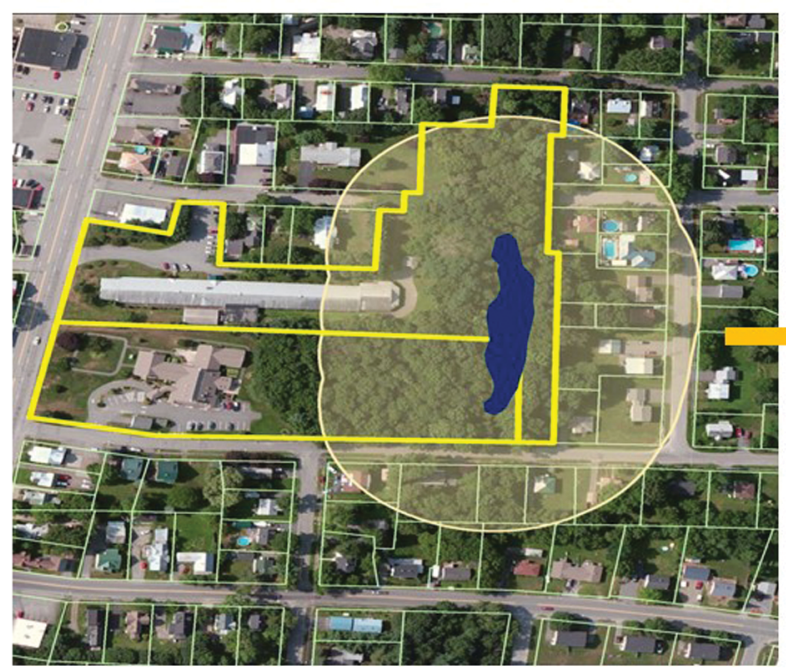

Vernal pools and surrounding land conserved in rural area

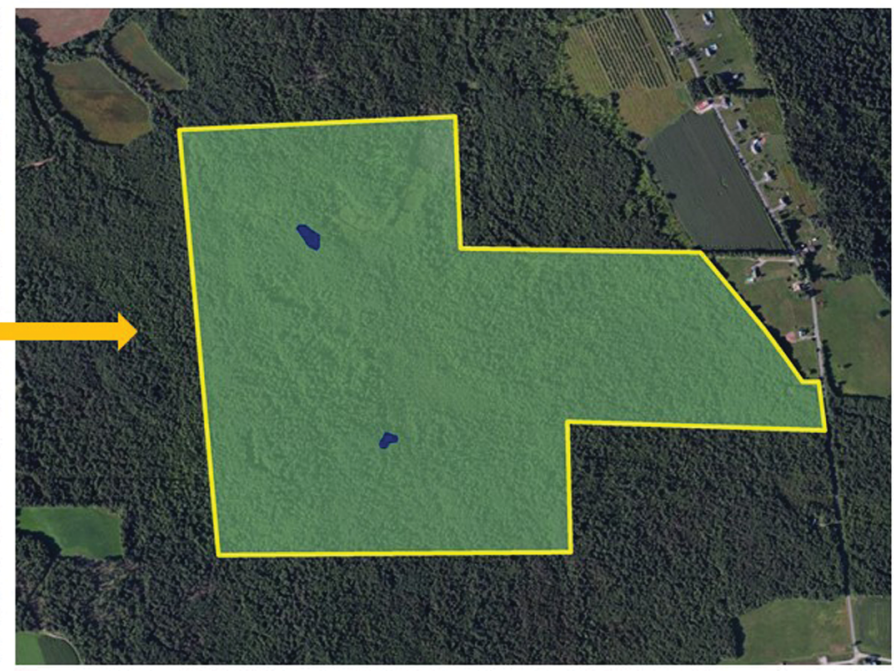

FIGURE 2. Vernal pool conservation requirements. The SAMP requires conservation of two high-quality vernal pools embedded in 70 acres of unfragmented forest in exchange for impacting one vernal pool in the DDA.

jurisdiction; a permit applicant chooses to use the SAMP instead of the standard regulatory process, the local land conservation organization agrees to partner with the municipality, and only willing rural landowners provide conservation opportunities. The SAMP expands options, rather than replacing or amending existing regulations. Finally, the voluntary aspect of the SAMP increased partners' tolerance for novelty and risk by ensuring existing regulations remained in place as a backstop.

\section{DISCUSSION}

In this case study, we have demonstrated how an approach to managing small natural features can be constructed through revision and creative combination of pre-existing tools, such as a federal management plan, state wetland regulations, municipal ordinances, conservation best practices, real estate appraisals, and collaborative partnerships. The landscape-scale approach employed in this mechanism has benefit for the natural resources, the regulators, and the regulated community. Case-by-case avoidance and minimization analysis of impacts to vernal pools in highly developed areas are not sufficient to ensure conservation of the landscape connections essential for maintenance of the diverse array of ecological, hydrological, and biogeochemical functions of pools in northeastern forests [6]. Thus, not only does a landscape approach secure enduring conservation for vernal poolscapes in unfragmented forested habitat but also it eliminates the need for developers to spend time and money undertaking an alternatives analysis, and it provides greater certainty and predictability for the permit applicant. This approach reduces the workload of both the federal and state regulators who otherwise must review the alternatives analysis and resulting mitigation packages on a case-by-case basis. It also provides a tool to towns that incentivizes compact, high-density development in certain locations, and preservation of rural character and resources in other locations.

The SAMP's landscape approach goes hand-in-hand with a focus on the local level ecological and economic context, from delegating permitting authority to municipalities, to calculating fees at a site-specific scale, to engaging local land trusts in conservation actions. The SAMP incentivizes compact, infill development, one feature of "smart growth." Using appraisals to determine the mitigation fee helps support the financial feasibility of development projects by developing a fee that is in line with current costs and profits of developing that property. The SAMP provides an incentive for growth and conservation based on the will of the community.

One risk of creating a new conservation tool is that it will not work for one or more of the stakeholders involved in its creation. In the SAMP, this risk was mitigated by a built-in adaptive management mechanism. Adaptive management is the iterative process of assessing how well an existing management mechanism is working and adjusting it as needed. 
The ecological and economic outcomes of the SAMP will be reviewed annually and edited or even eliminated if appropriate. The first municipality received authority to implement the SAMP several months before writing this manuscript, with a second municipality in the process of doing so. Although there have not yet been any projects that have used the SAMP to facilitate development and conserve vernal pools, there is a lot of excitement about its potential. If the interest of other communities to start the process of getting delegated authority for vernal pool regulation under the SAMP is any indication, the SAMP has a promising future in Maine.

\section{CONCLUSION}

When you have small, dispersed, natural features that depend on connections to larger ecosystems, traditional regulatory methods are often problematic. Shorebird feeding and roosting habitat as well as fisheries resources face similar issues to vernal pools in that they are often difficult to locate and monitor; they, too, are dynamic, and their functions are dependent on the condition of adjacent ecosystems. A non-traditional, voluntary approach backstopped by existing regulation, such as outlined in the SAMP, may be a solution for management of these types of natural resources.

\section{CASE STUDY QUESTIONS}

I. How does each key feature of the conservation mechanism address the stakeholder concerns outlined in Table $\mathrm{r}$ ?

2. What is a landscape approach to protecting resources and how does the SAMP provide this approach?

3. What are some advantages and disadvantages of a voluntary conservation mechanism?

4. Can you think of any other conservation challenges addressed with traditional regulation that could benefit from the SAMP approach? Explain how specific features of the SAMP could improve management of another difficult-to-regulate resource.

5. Which key feature do you find most interesting and why? Find an example of the use of this feature in another regulatory or management framework and compare how it is used in that example to how it is used in the SAMP.

\section{AUTHORS CONTRIBUTION}

All three authors, VL, AC, and EH, participated in the conceptualization, writing, reviewing, and editing of this article.

\section{FUNDING}

This work is partially funded by a National Science Foundation Coupled-Natural-Human-Systems grant (NSF CNH Award Number I 3 1 3627 of Pools and People: Small natural features with large ecosystem functions in urbanizing landscapes) and by a Region I Environmental Protection Agency Wetland Program Development grant.

\section{COMPETING INTERESTS}

The authors have declared that no competing interests exist.

\section{SUPPLEMENTARY MATERIALS}

I. Annotated slide deck, "The science behind the development of the Maine Vernal Pool SAMP" - provides background on the ecology of vernal pool ecosystems as applied to management strategies (PowerPoint).

2. Annotated slide deck, "How the Maine Vernal Pool Special Area Management Plan Works"- provides background on the process for implementing the SAMP (PowerPoint).

3. "Maine Municipal Guide to Mapping and Conserving Vernal Pool Resources"-provides information on the ecology, assessment and conservation of vernal pools at the local level using citizen scientists (PDF).

4. "A Special Area Management Plan for Vernal Pools in Maine" - the SAMP accepted by the Army Corps of Engineers (PDF).

5. "Supplemental Literature"-list of additional literature that is not cited in the case study about the social and ecological background of the Vernal Pool SAMP (Word). 


\section{REFERENCES}

I. Calhoun AJK, Mushet DM, Alexander LC et al. The significant surface-water connectivity of "Geographically Isolated". Wetlands. 2017: doi:10.1007/s13157.

2. Colburn E, Weeks SC, Reed SK. Diversity and Ecology of Vernal Pool Invertebrates. In: Calhoun AJK, DeMaynadier PG, editors. Science and Conservation of Vernal Pools in Northeastern North America. Boca Raton, FL: CRC Press; 2008. pp. 107-I 24.

3. Golden HE, Creed IF, Ali $G$ et al. Integrating geographically isolated wetlands into land management decisions. Front Ecol Environ. 20 17: doi: $10.1002 /$ fee. 1504.

4. Calhoun AJK, Mushet DM, Bell KP, Boix D, Fitzsimons JA, Isselin-Nondedeu F. Temporary wetlands: challenges and solutions for protecting a "disappearing" ecosystem. Biol Conserv. 2017;2 II: 3-1 I.

5. Hunter ML, Acuña V, Bauer DM et al. Conserving small natural features with large ecological roles: a synthetic overview. Biol Conserv. 20 17;2 I I: 88-95.

6. Cohen MJ I, Creed F, Alexander L et al. Do geographically isolated wetlands influence landscape functions? Proc Natl Acad Sci US A. 201 6; I 1 3: 1 $978-1986$.

7. Mushet DM, Calhoun AJK, Alexander LC et al. Geographically isolated wetlands: rethinking a misnomer. Wetlands. 20I 5;35: 423-43 I.

8. Creed IF, Lane CR, Serran JN et al. Enhancing protections for vulnerable waters. Nat Geosci. 20 1 7; I0: 809-8 I 5 .

9. Semlitsch RD. Principles for management of aquaticbreeding amphibians.J Wildl Manage. 2000;64: 6 I 5-63 I.

ı. Semlitsch RD, Bodie JR. Biological criteria for buffer zones around wetlands and riparian habitats for amphibians and reptiles. Conser Biol. 2003;1 7: I 21 9-I 228.

I I. Homan RN, Windmiller BS, Reed JM. Critical thresholds associated with habitat loss for two vernal pool-breeding amphibians. Ecol Appl. 2004; I 4: I 547-I 553.

12. Skidds DE, Golet FC, Paton PWC, Mitchell JC. Habitat correlates of reproductive effort in wood frogs and spotted salamanders in an urbanizing watershed. $J$ Herpetol. 2007;41: 439-450.

13. Windmiller BS, Homan RN, Regosin JV, Willetts LA, Wells DL, Reed JM. Breeding Amphibian Population Declines Following Loss of Upland Forest Habitat Around Vernal Pools in Massachusetts, USA. In: Mitchell JC, Jung Brown RE, Bartholomew B, editors. Urban Herpetology. Salt Lake City: Society for the Study of Amphibians and Reptiles; 2008. pp. 4I-5I.

14. Homola J. Ecoevolutionary Implications of Environmental Change Across Heterogeneous Landscapes. Dissertation. Orono, ME, USA: University of Maine; 2018.

I 5. Mahaney, W. S., and M. W. Klemens. 2008. Conserving vernal pools in human-modified landscapes vernal pool conservation policy: the federal, state, and local context. Pages I93-2 I 2 in A.J.K. Calhoun and P.G. deMaynadier, editors. Science and conservation of vernal pools in northeastern North America. CRC Press, Boca Raton, Florida, USA.

16. Levesque V, Calhoun AJK, Bell KP. Turning contention into collaboration: engaging power, trust, and learning in collaborative networks. Soc Nat Resour. 20 1 7;30(2): 245-260.

17. Davis BC. Regional planning in the US coastal zone: a comparative analysis of is special area plans. Ocean Coastal Manage. 2004;47(I-2): 79-94.

18. US Army Corps of Engineers. December 7, 2005. Regulatory Guidance Letter 05-09, Subject: Special Area Management Plans. 2005.

19. Calhoun AJK, Jansujwicz JS, Bell KP, Hunter ML Jr. Improving management of small natural features on private lands by negotiating the science-policy boundary. Proc Natl Acad Sci US A. 201 4; I I I: 1 1 002 - I 1006.

20. McGreavy B, Calhoun AJK, Jansujwicz J, Levesque V. Citizen science and natural resource governance: program design for vernal pool policy innovation. Ecol Soc. 20 1 6;2 1: 48. doi: 10.575 I/ES-08437-210248. 